\title{
Soluble CD30 and peripheral blood or pulmonary involvement of adult T-cell leukemia/lymphoma
}

\author{
Shigeki Takemoto ${ }^{1,2 *}$ and Ratiorn Pornkuna ${ }^{1,3}$ \\ ${ }^{1}$ Department of International Cooperation, Graduate School of Medical Sciences, Kumamoto University, Japan \\ ${ }^{2}$ Clinical Laboratory, National Hospital Organization Kumamoto Medical Center, Japan \\ ${ }^{3}$ Nursing Department, KhonKaen Regional Hospital, Thailand
}

Adult T-cell leukemia/lymphoma (ATL) is a highly aggressive leukemia/lymphoma which was discovered in Japan [1,2]. The long clinical latency and low incidence of ATL indicate that ATL is an agerelated disease and some genetic changes are involved in malignant transformation and monoclonal expansion of the human T-cell leukemia virus type 1 (HTLV-1)-infected cells [3]. HTLV-1-mediated $\mathrm{T}$-cell transformation presumably arises from a multistep oncogenic process in which the virus induces chronic T-cell proliferation with accumulation of genetic defects followed by dysregulation of cell growth [4]. Monoclonal proliferation of HTLV-1-infected cells is observed in upwards of $5 \%$ of patients who ultimately develop ATL, constituting the high risk group for ATL development [5]. We previously reported that HTLV-1-infected cells and ATL cells exhibit $\mathrm{CD} 30$ and soluble $\mathrm{CD} 30$ (sCD30) is elevated in the sera of patients with ATL [6]. CD30, a $120 \mathrm{kDa}$ type I cell surface glycoprotein, is a member of the tumor necrosis factor receptor superfamily [7]. CD30 expression is dependent on mitogen or viral activation and proliferation of $\mathrm{B}$ and $\mathrm{T}$ cells. CD30+ cells release sCD30 in vitro and in vivo [8], detected at low levels in the sera of healthy donors [9].The question remains as to where the ATL cells proliferate and produce SCD30? We have focused on the monoclonal proliferation of $\mathrm{T}$ cells and chronic inflammation in the microenvironment in vivo.

Peripheral Blood (PB) is known as one of unique involvements in ATL. Mononuclear cells from PB of acute type ATL patient show the proliferation of CD4+ T cells (Figure 1). In contrast, some T cells are shown in PB of HTLV-1 carrier. Levels of sCD30 are elevated in HTLV-1 carriers, becoming highly elevated in ATL. Lately, we found serum levels of sCD30 is correlated with the number of ATL cells in PB (data not shown). Furthermore, sCD30 elevation is followed by acute crisis from chronic type of ATL (paper preparation).

Ohshima et al. demonstrated that not only CD3+ and CD4+ T cells

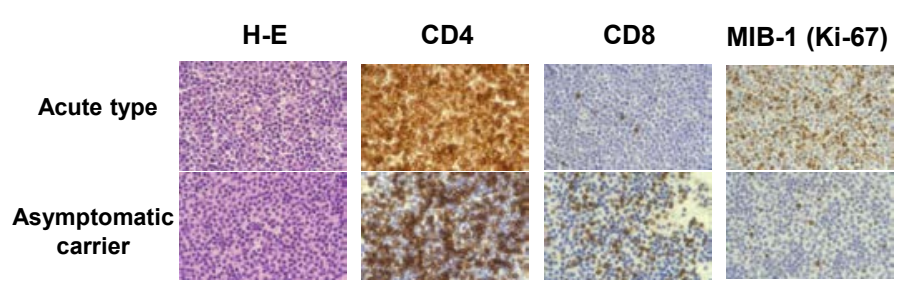

Figure 1. Proliferation of CD4+ T cells in peripheral blood of HTLV-1-infected patient.

Paraffin embedded specimens of peripheral blood mononuclear cells (PBMCs) were compared between an acute type of ATL patient and a HTLV-1 carrier. Most of PBMCs from a patient with ATL showed the proliferating CD4+CD8- T cells (MIB-1, Ki-67) but not PBMCs from a HTLV-1 carrier. but also CD30+ giant cells are infected with HTLV-1 in lymph node (LN) [10]. However, CD30+ cells are not always found in LN (Table 1).

Lung involvements are often found from the onset of ATL, suggesting that lung is suitable for the formation of the tumor microenvironment [4]. The tumor viruses such as HTLV-1 and Epstein Barr virus induce $\mathrm{CD} 30$ expression and $\mathrm{sCD} 30$ production in virusinfected cells. Furthermore, those viruses are associated with unique lung diseases including HTLV-1 associated bronchiolo-alveolar disorder, HTLV-1 associated bronchopneumopathy, and pyothoraxassociated lymphoma. We recently found the elevation of sCD30 is associated with pulmonary involvement during therapy (data not shown). In case of allogeneic hematopoietic stem cell transplantation, serums CD30level is significant predictor of overall survival and specially detector of early death with lung lesions (paper preparation).

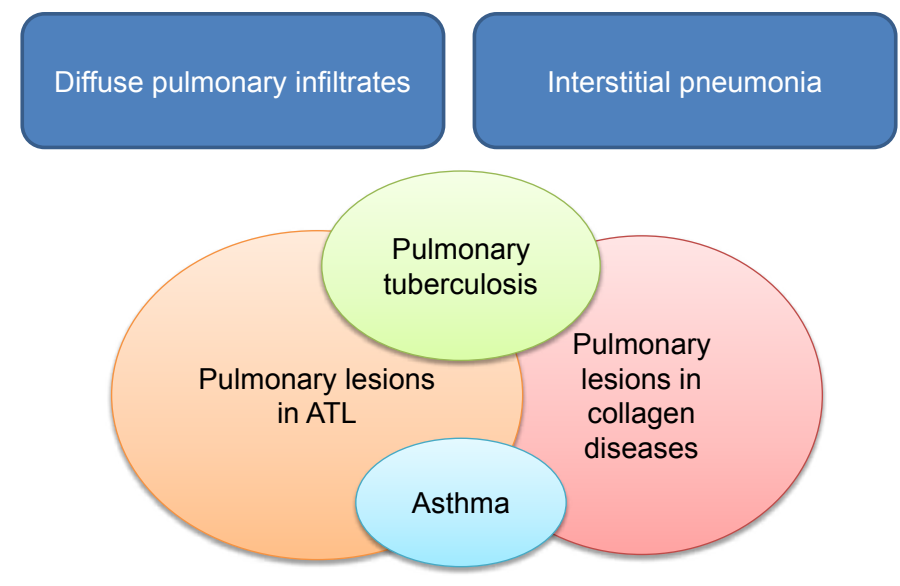

Figure 2. Lung diseases with tissue remodeling.

Activation of matrix metalloproteinases, ADAM10 and ADAM17, are associated with severe lung diseases which accompany tissue remodeling.

Correspondence to: Dr. Shigeki Takemoto, M.D, Ph.D, Chief of Clinical laboratory, National Hospital Organization Kumamoto Medical Center, 1-5 Ninomaru, Kumamoto 860-0008, Japan, Tel: +81-96-353-6501; Fax: +81-96325-2519, E-mail: takemots@kumamed.jp

Key words: adult T-cell leukemia/lymphoma (ATL), human T-cell leukemia virus type 1 (HTLV-1), soluble CD30 (sCD30), microenvironment, pulmonary involvement

Received: September 11, 2014; Accepted: September 26, 2014; Published: October 02, 2014 
Table 1. Serum levels of soluble cytokine receptors and tumor involvement.

\begin{tabular}{|l|c|c|}
\hline Involved organs & $\begin{array}{c}\text { Soluble IL-2R } \boldsymbol{\alpha} \text { chain } \\
\text { (sIL-2R) }\end{array}$ & $\begin{array}{c}\text { Soluble CD30 } \\
\text { (sCD30) }\end{array}$ \\
\hline Peripheral blood $(\mathrm{PB})$ & High $\sim$ Very high & High $\sim$ Very high \\
\hline Lymph node $(\mathrm{LN})$ & High & Low $(\sim$ High $)$ \\
\hline Lung & High & High \\
\hline
\end{tabular}

Serum levels of sCD30 may be not only biomarker of ATL, but also marker of Matrix Matalloproteinases (MMPs) activation onHTLV-1infected cells and/or other cells in microenvironment. A disintegrin and metalloproteinase (ADAM) 10 and ADAM17 play a role for shedding of CD30 [11]. These MMPs also cleave collagen and elastin which is structural proteins of lung. It is speculated that lung diseases with tissueremodeling share a common factor which is possible target of therapy (Figure 2).

\section{References}

1. Takatsuki K (2005) Discovery of adult T-cell leukemia. Retrovirology 2: 16. [Crossref]

2. Uchiyama T, Yodoi J, Sagawa K, Takatsuki K, Uchino H (1977) Adult T-cell leukemia: clinical and hematologic features of 16 cases. Blood 50: 481-492. [Crossref]

3. Pornkuna R, Wongkhantee S, Jinathongthai S, Shimogawa S, Takemoto S (2014) Effect of blood transfusion on supportive therapy of elderly patients at Kumamoto, Japan as compared with Khon Kaen, Thailand. J Hematol Thrombo Dis 2: 152.
4. Pornkuna R, Takemoto S (2014) A lack of cellular senescence, formation of microenvironment, and role of soluble CD30 in development of adult T-cell leukemia/ lymphoma. J Hematol Thrombo Dis 2: 151.

5. Takemoto S, Matsuoka M, Yamaguchi K, Takatsuki K (1994) A novel diagnostic method of adult T-cell leukemia: monoclonal integration of human T-cell lymphotropic virus type I provirus DNA detected by inverse polymerase chain reaction. Blood 84 : 3080-3085. [Crossref]

6. Nishioka C, Takemoto S, Kataoka S, Yamanaka S, Moriki T, et al. (2005) Serum level of soluble CD30 correlates with the aggressiveness of adult T-cell leukemia/lymphoma. Cancer Sci 96: 810-815. [Crossref]

7. Horie R, Watanabe T (1998) CD30: expression and function in health and disease. Semin Immunol 10: 457-470. [Crossref]

8. Hansen HP, Dietrich S, Kisseleva T, Mokros T, Mentlein R, et al. (2000) CD30 shedding from Karpas 299 lymphoma cells is mediated by TNF-alpha-converting enzyme. $J$ Immunol 165: 6703-6709. [Crossref]

9. Krampera M, Vinante F, Tavecchia L, Morosato L, Chilosi M, et al. (1999) Progressive polarization towards a $\mathrm{T}$ helper/cytotoxic type- 1 cytokine pattern during age-dependent maturation of the immune response inversely correlates with CD30 cell expression and serum concentration. Clin Exp Immunol 117: 291-297. [Crossref]

10. Ohshima K, Niino D, Karube K (2014) Microenvironment of adult T-cell leukemia/ lymphoma-associated nodal lesions. Int J Hematol 99: 240-248. [Crossref]

11. Pornkuna R, Nishioka C, Takemoto S (2014) What is the role of soluble cytokine receptors in adult T-cell leukemia/lymphoma? J Hematol Thrombo Dis 2: 154.

Copyright: (2014 Takemoto S. This is an open-access article distributed under the terms of the Creative Commons Attribution License, which permits unrestricted use, distribution, and reproduction in any medium, provided the original author and source are credited. 